\title{
Reforming International Organizations
}

\section{How Partisanship and Ministerial Control Shape State Preferences toward the World Bank}

\author{
Eugénia C. Heldt \\ TUM School of Governance, Technical University of Munich, \\ Munich, Germany \\ heldt@tum.de \\ Laura C. Mahrenbach \\ TUM School of Governance, Technical University of Munich, \\ Munich, Germany \\ laura.mahrenbach@tum.de
}

\begin{abstract}
Recent scholarship has highlighted the role of domestic pressures in determining state preferences toward the reform of international organizations (IO s). This article adds a new dimension by examining how partisanship and ministerial control affect state preferences toward IO empowerment. The article derives two expectations from the existing literature. First, partisan position will determine preferences toward IO empowerment. Second, when a government is constituted by multiple parties, the position of the party with the IO's ministerial portfolio will determine the government's position toward IO empowerment. The article illustrates this argument by examining the positions of four net donors (Germany, France, the United Kingdom, and the United States) and two net recipients (Brazil and India) during the World Bank's reforms. By bringing domestic politics back in, this article complements existing studies on the politics of IO reform and weighs in on central debates in comparative politics and international political economy.
\end{abstract}

\section{Keywords}

World Bank - international organizations - empowerment - partisanship - state preferences - domestic politics 
Between 2007 and 2012, the World Bank (henceforth, the Bank or WB) underwent a series of reforms in response to ever louder calls for the institution to adapt to the changing world economy. Members agreed to increase the Bank's capital through quota reforms enhancing the representation of developing and emerging economies, and by creating new funds and financial instruments. They also agreed to widen the Bank's mandate and established new programs addressing issues ranging from climate change and trade to agriculture, food security, energy, water, and health. ${ }^{2}$ These developments present us with a set of conundrums. Why would net donors of development assistance agree to provide the Bank with more funds and compromise their dominant position in the Bank precisely when their own economies were in need of economic stimulus? And why would net recipients of aid, and particularly rising powers protective of state sovereignty, ${ }^{3}$ agree to a more intrusive Bank mandate and programs when they were likely to be immediately affected by such changes?

While the rational choice and principal-agent literatures focus on how and why incentives and institutional structures mediate between preferences and outcomes, ${ }^{4}$ we adopt a domestic politics perspective to better understand these puzzles. ${ }^{5}$ Specifically, we examine how the partisan composition of governments, and ministerial control over an international organization (IO) portfolio, affects state preferences toward IO empowerment (IOE). Empowerment refers here to the delegation of decision-making authority and resources to IOs. It has two dimensions. First, IOs can be empowered relative to the services they provide. This includes the extent to which IOs collect information, monitor states' compliance, are in charge of implementing policies or distributing funds, and the breadth of policy areas within their mandates. State support for

1 This research has received funding from the European Research Council under the European Union's Seventh Framework Programme for research, technological development, and demonstration under Grant Agreement No. 312368 DELPOWIO (Delegation of Power to International Organizations and Institutional Empowerment over Time). Special thanks go to the editors of Global Governance, particularly J. Matthew Clarke, and to the two anonymous reviewers for their insightful comments on an earlier version of this article. We are also grateful to Patrick Mello, Vittoria Meissner, Tony Müller, André Isidro, Henning Schmidtke, Jamie Gaskarth and the participants of the International Studies Association Annual Meeting in Atlanta 2016 for their comments on previous versions of this article.

2 Vestergaard and Wade 2015 .

3 Heldt 2017; Heldt and Mahrenbach 2018; Heldt and Schmidtke 2019a; Mahrenbach 2o19a.

4 Koremenos, Lipson, and Snidal 2001; Hawkins et al. 2006.

5 Moravcsik 1997; Milner 1997; Conceição-Heldt 2011. 
expanding IO tasks or programs, creating new programs, and widening an IO's mandate reflect support for this type of IOE. Second, empowerment can be measured relative to the material resources an IO has at its disposal, including the size of an IO's staff and budget. ${ }^{6}$ Support for this type of IOE is present when states provide an IO with more resources, create new financial instruments, or agree to expand IO staff. Ceteris paribus, opposition to IOE is evident when states oppose expanding IO services or enhancing IO resources. State preferences are defined here as the positions that governments take on delegating authority and resources to IO s. Parties can either oppose, conditionally support, or strongly support IOE.

We derive two expectations from the existing literature on partisanship and international cooperation. First, governments' partisan positions will determine their preferences toward IOE. Second, when governments are constituted by multiple parties, the position of the party controlling an IO's ministerial portfolio will determine the government's preferences on IOE. We probe these expectations through case study investigations of four net donorsFrance, Germany, the United Kingdom, and the United States-and two net recipients - Brazil and India - of development assistance during the WB reforms negotiated in the wake of the global financial crisis of $2007-2012 .{ }^{7}$ By examining net contributors and net recipients of WB financial aid, our case selection takes into account countries' positions in the global economy and also engages with the global governance literature investigating shifts in global power structures. ${ }^{8}$ We find clear support across Bank net donors and recipients that partisan positions and ministerial control affect state preferences toward IOE at the Bank.

\subsection{Partisan Politics at the World Bank}

Previous studies have pointed to several international factors that have shaped Bank reforms and the effectiveness of its development goals. These include the Bank's bureaucratic culture, poor management, institutional design, accountability, and the Bank's ability to remain a focal institution in global develop-

6 Heldt and Schmidtke 2017.

7 Due to our focus on partisan politics, we compare only democracies with multiple parties at the domestic level in this contribution. We are aware that our theoretical framework is less useful in two-party states, such as the United States, where a single party may incorporate a more diverse set of ideologies and positions. However, given the United States' role as the Bank's largest net donor, we include this country in our analysis.

8 Coen and Pegram 2015; Fioretos and Heldt 2019; Heldt and Mahrenbach 2018; Heldt and Schmidtke 2019a, 2019b; Mahrenbach 2013, 2015, 2019b. 
ment finance. ${ }^{9}$ Yet other scholars have underlined the role played by domestic factors, including national norms, foreign policy strategies, interest groups and civil society pressure. ${ }^{10}$ In this article, we add to this literature by focusing on two neglected domestic factors-partisan politics and ministry control-to explain state preferences toward Bank reforms.

Two logics in the existing literature explain how political parties affect international cooperation and, thus, how partisanship may be linked with state preferences toward IOE. The party competition logic suggests that government positions regarding international cooperation may differ depending on whether parties have to compete or cooperate, as well as on individual parties' relative presence in the national policy-making context. Examples include the need to cooperate with extremist or niche parties to achieve legislative goals unrelated to international cooperation, and the strategic disclosure of information by opposition parties during international negotiations, both of which can limit the executive's capacity to cooperate internationally. ${ }^{11}$ The domestic institutions logic, in contrast, focuses on how the domestic institutional context affects preferences toward international cooperation. Relevant institutional factors include executive-legislative (dis)agreement and how vulnerable a government is to lobbying. ${ }^{12}$ While the former logic implies that party competition may hinder governments' willingness to support IOE, the latter is ambiguous in its predictions. Both agree, however, that partisan politics affect cooperation. Building on this, we proffer our first expectation, namely, that a government's partisan position affects state preferences toward IOE.

However, few countries are actually governed by one party. This raises the question of how partisan preferences and ministry control shape state preferences on IOE when a coalition government is in office. Research suggests that the party in charge of a certain portfolio is more likely to influence outcomes on that policy issue. ${ }^{13}$ Portfolio allocation within a coalition government allows portfolio holders to implement their ideal points within a certain issue area (e.g., trade, development, or finance). ${ }^{14}$ Mark Hallerberg refers to this structure as "fiefdom" government, where "ministers have relative autonomy over decisions in their jurisdiction," acting essentially as "lords of their ministerial

\footnotetext{
$9 \quad$ Clegg 2010; Wade 2010; Weaver 2007; Jakobeit 2004; Park 2017; Heldt 2018; Heldt and Schmidtke 2019b.

$10 \quad$ Winters and Kulkarni 2014; Woods 2008; Andersen, Hansen, and Markussen 2006.

11 Finke and Dannwolf 2013; Camyar 2012; Crawford 1996; Heldt 2020.

12 Milner 1997; Conceição-Heldt 2011; Conceição-Heldt and Mello 2018.

13 Müller and Strøm 2000.

14 Strøm, Müller, and Smith 2010.
} 
fiefdoms." ${ }^{15}$ From this perspective, portfolio allocation offers opportunities to parties in a coalition government to control certain policy fields. In addition, portfolio holders have the power to put their imprint on specific issue areas. Hence, our second expectation: when parties in government have different preferences, the position of the party with the ministerial portfolio is more likely to determine the government's position toward IOE. Ministerial control of an IO portfolio and partisan preferences will consequently be examined together in all six case studies.

\subsection{Partisan Preferences and IOE}

Partisan preferences were determined in two steps. Drawing on the existing literature, we first identified five party groups (left, social democratic, liberal/Christian democratic, conservative, right) and their expected preferences toward international cooperation and IOE, relying primarily on categorizations by Arndt Wonka, Ryan Bakker et al., and Gary Marks, Carole J. Wilson, and Leonard Ray. ${ }^{16}$ These contributions propose diverse characteristics defining different party groups. For instance, while both left and social democratic parties support policies promoting citizen welfare and development, left parties justify these pursuits in the language of "social justice" whereas social democrats simply seek economic opportunities for all citizens. ${ }^{17}$ Subsequently, we looked for evidence of distinguishing characteristics in party manifestos and publications issued by parties holding office in the six countries during the period of our analysis. These include documents such as the German Free Democratic Party's manifesto of 2009, and the Indian coalition government's reports to the people in 2005 and 2012. Based on these primary sources, we classified individual parties into groups. For this purpose, we consulted existing work when classification was unclear on the basis of party manifestos alone. As far as possible, we also checked all classifications against extant categorization databases. ${ }^{18}$

We distinguish three types of support for IOE: opposition, conditional support, and strong support. Opposition means that a party opposes the expansion of an IO's services or resources. Wonka shows that the further parties move away from the ideological center, the more critical they are of the European Union (EU). ${ }^{19}$ Extrapolated to global governance, this suggests that left and

\footnotetext{
15 Hallerberg 2004, 16.

16 Wonka 2016; Bakker et al. 2012; Marks, Wilson, and Ray 2002.

17 Marks, Wilson, and Ray 2002.

18 For example, see Döring and Manow 2016.

19 Wonka 2016.
} 
right parties should be opposed to IOE. Left parties generally view international cooperation as undemocratic, with IO s institutionalizing a liberal economic world order that increases economic inequality and advances the interests of the most powerful. ${ }^{20}$ IOE would reinforce these characteristics. Consequently, these parties are more likely to oppose IOE. Right parties, in turn, view IOs as undermining national sovereignty, culture, and democracy, and limiting the state's regulatory capacity. ${ }^{21}$ They consequently support exit from IO s (e.g., Alternative for Germany) ${ }^{22}$ and are unlikely to support IOE.

Conditional support for IOE is present when parties favor international cooperation in general, but will support IOE only if certain conditions are fulfilled. For example, social democratic parties support IOE conditional on the inclusion of social, environmental, and labor standards in IO programs and/or on IOE initiatives being capable of enhancing states' economic growth, welfare, and regulatory capacity (e.g., Democratic Party). ${ }^{23}$ Likewise, conservative parties can be expected to support IOE that institutionalizes liberal economic policies and minimizes government intervention in the economy, but oppose IOE that increases constraints on state sovereignty or requires additional state resources to implement. ${ }^{24}$

Strong support is present when parties favor international cooperation and IOE unconditionally, viewing both as useful means of achieving their goals. Liberal and Christian democratic parties have been consistent supporters of advancing European integration, ${ }^{25}$ and programmatically support international cooperation in general. Christian democratic parties see IOs as a means of constraining nationalism, supporting liberal economic policies, and enhancing citizen welfare (e.g., Christian Democratic Union). ${ }^{26}$ Liberal parties consider IOs to be indispensable for reducing the transaction costs of international cooperation and institutionalizing liberal principles such as limiting state intervention in the economy, decreasing market regulation, and maximizing economic efficiency and productivity (e.g., Free Democratic Party). ${ }^{27}$ As such, parties in both groups can be expected to support the enhancement of these characteristics through IOE. Table 1 summarizes the expected IOE preferences of each party group.

\footnotetext{
20 Communist Party of India [Marxist] 2014.

21 Marks, Wilson, and Ray 2002.

22 Alternative for Germany 2017.

23 Democratic Party 2012.

24 Marks, Wilson, and Ray 2002; see also Republican Party 2012.

25 Bakker et al. 2012.

26 Christian Democratic Union 2009.

27 Free Democratic Party 2009.
} 
TABLE 1 Party preferences toward international organization empowerment (IOE)

Party group IOE preferences

\begin{tabular}{lc} 
Left & - \\
Social democratic & + \\
Liberal and Christian democratic & ++ \\
Conservative & + \\
Right & - \\
\hline
\end{tabular}

-, opposition; +, conditional support; ++, strong support

Methods

We illustrate our argument by examining how party affiliation affects state preferences toward IOE in six case studies. This part of the analysis draws on seventy-one statements by national representatives before the World Bank's Development Committee between 2007 and 2012. The cases were selected to demonstrate variation in whether states are net donors or net recipients of development assistance. ${ }^{28}$ This is a key factor affecting development policy ${ }^{29}$ and, therefore, an important distinction when examining how states view IOE at the Bank. Regarding net donors, our sample includes the Bank's four biggest donors (in decreasing order: the United States, Germany, the United Kingdom, and France) as measured in 2010, that is, in the midst of the reforms examined here. ${ }^{30}$ This yielded a corpus of forty-seven texts, or roughly twelve texts per country. With regard to development assistance, India has been the largest net recipient of loans from the Bank for seventy years, followed by Brazil and China. ${ }^{31}$ We obtained a corpus (twenty-four texts, with twelve per country) comparable to that of net donor countries. In their statements,

28 Our sample also includes variation on the type of government in office (one-party, twoparty, and multiparty coalition governments) during the reform negotiations. Admittedly, our small-n study provides only unsystematic data on this variable. Future research could expand on this study by collecting data on the type of government for a bigger sample of member states and also by extending the comparison of IOE reforms over time.

29 White and Morrissey 1998.

30 World Bank 2010.

31 A third logical choice as net recipient is China. However, we excluded China due to its status as an autocratic regime with a single-party system. For an analyis of China's role in global economic institutions, see Woods 2010; Chin 2014; Heldt and Schmidtke 2019a. 


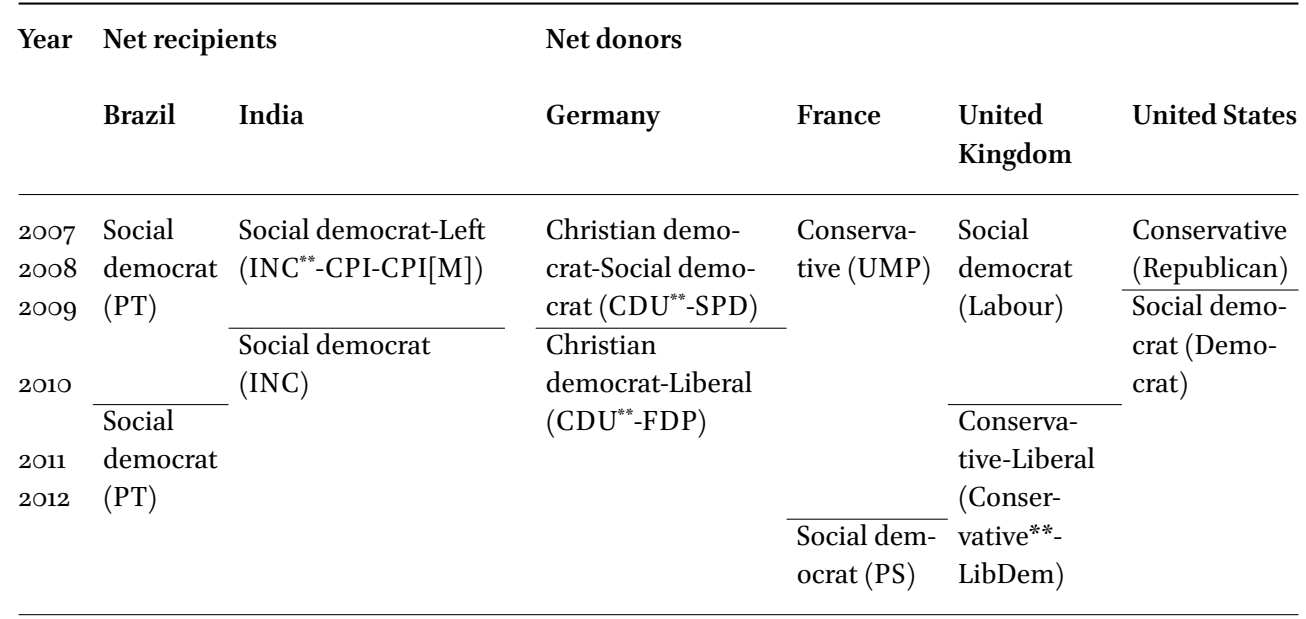

Sources: Data collected from home pages of relevant institutions in each country as well as from the PARLINE database (Inter-Parliamentary Union 2015).

* In parliamentary systems, parties in government refers to those either holding a majority in parliament or which are members of a ruling coalition. In presidential systems, parties in government refers to the party of the president.

*** Dominant party in ruling coalition.

Brazil and India explicitly claim to speak on behalf of thirteen developing countries. As is evident in Table 2, all countries were ruled by two successive governments during the Bank reforms, enabling comparison within and across cases.

The analysis proceeds in two steps. First, we conducted a content analysis of national statements to determine individual governments' positions vis-àvis empowerment of the World Bank. This method involved deep and focused reading of a textual corpus to determine themes that characterize a text. ${ }^{32}$ This allowed us to identify both government positions toward Bank empowerment and positions reflecting officials' party affiliation. ${ }^{33}$ Content analysis enabled us to examine how party ideology affects IOE preferences. Second, we used the findings from the content analysis to determine whether government positions changed as parties with different preferences assumed office. This took the form of exploratory case studies comparing stated partisan positions of single governments over time.

$32 \quad$ Krippendorf 2013; Hsieh and Shannon 2005.

33 Milliken 1999. 
Both of the expectations examined here placed partisan positions and ministry control at the center of explaining member states' preferences toward Bank empowerment. However, we would have been remiss not to control for claims that competition and cooperation among parties related to parties' relative presence in policy-making discussions, or that conflict between preferences in different domestic institutions may also affect government positions. Consequently, we additionally considered seat distribution among parties in national parliaments in all twelve governments, looking particularly at the impact that coalition partners and opposition parties may have on state preferences toward IOE.

\subsection{Net Donors and WB Empowerment 2.1.1 Germany}

During the WB reforms, two-party coalitions held national office in Germany. The first coalition united the Christian Democratic Union (CDU)/Christian Social Union (CSU) political alliance under the leadership of Chancellor Angela Merkel with the Social Democratic Party (SPD). It was in office through late 2009. During this "grand coalition" of Germany's two largest parties, the SPD's Heidemarie Wieczorek-Zeul represented Germany at the WB. Subsequently, from November 2009 to October 2013, the CDU/CSU built a coalition with the liberal Free Democratic Party (FDP). In this second coalition government, Dirk Niebel from the FDP was in charge of the development portfolio.

Legislative seats were distributed relatively evenly within the grand coalition, with the CDU-CSU alliance controlling 226 and the SPD 222 seats. The distribution was more uneven in the second period-239 for the CDU/CSU and 93 for the FDP. The second government thus provides a particularly strong illustration of our argument that ministerial portfolio control is relevant in determining whose partisan positions matter for state preferences toward WB empowerment.

The first German government supported IOE. On the services side, Minister Wieczorek-Zeul promoted widening the Bank's mandate to include climate change and the creation of new rules to fight tax evasion. ${ }^{34}$ These preferences reflected social democratic support for enhancing states' regulatory powers and promoting IOE that facilitates environmental protection. However, the justifications given for improved regulation-for example, developing "efficient, transparent tax systems"35_aligned closely with Christian democratic

34 For instance, Wieczorek-Zeul 2007b.

35 Wieczorek-Zeul 2oog, 3. 
support for a liberal economic order. On the resources side, Wieczorek-Zeul urged members to enhance funding for members' climate change, energy and development concerns, ${ }^{36}$ echoing social democratic preferences. The Christian democratic party's support for increasing economic efficiency is also evident in environmental statements: "Those responsible for causing global climate change will be called upon to pay the costs and the revenue thus generated will finance climate protection for those worst hit." ${ }^{37}$ The coalition's position toward IOE accordingly reflects the partisan positions of both social and Christian democrats, who were expected to support IOE conditionally on the inclusion of environmental issues and liberal principles in Bank activities.

The transition to a Christian democratic-liberal government in 2009 meant that the development portfolio shifted to the liberal party. Regarding the services dimension of IOE, Dirk Niebel supported the expansion of the Bank's mandate to include climate change. ${ }^{38}$ While this position was similar to that of the preceding government, statements from the new development minister favoring the introduction of new rules to strengthen the participation of the private sector in development programs, ${ }^{39}$ and underlining the importance of decreasing the transaction costs of cooperation by implementing new procedures ${ }^{40}$ indicated clear alignment with liberal positions. Turning to resources, Niebel recognized that the Bank might require new financial mechanisms or an expansion of the Bank's capital base to better respond to crisis situations in the future. ${ }^{41}$ However, he also considered that a capital increase would not solve the Bank's financial problems if members failed to "deploy the Bank's existing capital and resources in a more efficient and flexible way." ${ }^{22}$ In framing IOE initiatives in terms of liberal economic principles, these statements affirm the relevance of partisan positions in influencing government preferences toward IOE.

On portfolio control, too, the evidence appears supportive. The strong emphasis on environmental issues in the grand coalition, followed by the prominence of liberal preferences in the CDU/CSU-FDP government, confirmed our expectation. Interparty competition was equally relevant in the case of the CDU-CSU/SPD government: the balance of social democratic and Christian

\footnotetext{
36 Wieczorek-Zeul 2007a, 2009.

37 Wieczorek-Zeul 2009, 3.

$3^{8} \quad$ Niebel 2013, 2.

39 Niebel 2ona.

40 Niebel 2010, 3.

41 For example, Niebel 2oub.

42 Niebel 2012, 3.
} 
democratic positions in the German government's stated preferences reflects the balance of governing parties' seats in the Bundestag.

\subsubsection{France}

France was governed by one-party governments during the reform negotiations. Through May 2012, a conservative Union for a Popular Movement (UMP) government under President Nicolas Sarkozy was in power. UMP economic ministers Christine Lagarde and François Baroin represented France at the Development Committee during this government. In June 2012, a social democratic government led by the Socialist Party (PS) of President François Hollande took office. During this government, France was represented by PS ministers Pierre Moscovici and Michel Sapin. ${ }^{43}$

The UMP controlled a majority of seats in the French National Assembly during the first government: 313 to the 186 held by the second-largest party, the PS. The margin was narrower but still substantial in the Senate, with the UMP controlling 151 to the PS's 116 seats. During the second government, the PS gained the upper hand in the National Assembly, controlling 280 seats to the UMP's 194. However, the parties were relatively evenly matched in the Senate, with the UMP and PS controlling 132 and 127 seats respectively. In other words, in both governments, the ruling party faced substantial opposition in parliament.

Statements from the conservative government show support for IOE. French officials repeatedly advocated expansion of the Bank's mandate, programs, and resources to address climate change. ${ }^{44}$ They additionally supported the 2010 capital increase, called for more financial resources for Bank programs, and supported the creation of new financial mechanisms to handle future financial crises..$^{45}$ These preferences appear to contradict our expectations regarding conservative parties, which could be expected to oppose both incorporating climate change and additional financial contributions. Regarding the latter, however, closer examination reveals that the UMP rarely attributed responsibility for increased contributions to France. For instance, Minister François Baroin contended that a capital increase would help "make the Bank a robust, sustainable financial institution that generates the resources it needs to fulfil its mission," 46 essentially arguing that the Bank should procure its own

43 Given the limited chronological overlap of the PS government with the analytical period, fewer data were available to illustrate our propositions during the second government.

$44 \quad$ For example, Lagarde 2008.

45 Lagarde 2007, 2009, 2010a.

46 Baroin 2011, 2. 
additional resources. Other statements tasked "new donors" and "countries whose economic weight has increased" with providing said resources. ${ }^{47}$ Further, Baroin's statement illustrates that France viewed the Bank-fiscally stable, self-sustaining - as an example of the ideals shaping the liberal world order. Thus, while support for IOE for environmental purposes does indeed contradict our expectations, support for resource IOE is compatible with conservative party positions.

The 2012 election shifted the development portfolio to the social democratic PS. Like its predecessor, the PS supported expanding the Bank's mandate and resources to address climate change, arguing that efforts to fight poverty would be unsuccessful if member states disregarded the impact of climate change on development. ${ }^{48}$ Beyond this, PS statements had less in common with their UMP counterparts. Minister Moscovici's support for resource empowerment was justified as a means of improving labor rights rather than as a reaction to capital constraints arising from the global financial crisis. For example, Moscovici approved the creation of a transition fund to support job creation in the Middle East and another to "enhance the economic benefits for the people" arising from extractive industries in Africa ${ }^{49}$ As such, expressed preferences aligned with our expectations for social democratic parties on the two dimensions of the Bank's empowerment, namely services (inclusion of environmental issues) and resources (institutionalizing labor concerns).

This evidence also provides some support for the portfolio control logic. While support for incorporating climate change in the Bank's mandate was constant across both governments, and thus speaks against this expectation, we saw significant changes in the rhetoric promoting resource IOE in both. By contrast, the evidence did not support the domestic institutions logic. The UMP controlled the presidency and had a substantial margin in the French parliament during the first administration. Hence, while appeals to include climate change could be interpreted as appeals to the social democratic bloc in parliament, this would not be predicted by the domestic institutions' logic. By contrast, the PS executive branch had more cause to appeal to conservative preferences during its tenure, given its narrower legislative control. Yet here we see exclusively social democratic positions reflected in IOE preferences.

47 Lagarde 2o1ob, 1.

48 Moscovici 2013.

49 Moscovici 2012, 1. 


\subsubsection{The United Kingdom}

Through May 2010, the social democratic Labour Party held a majority in the House of Commons, forming a one-party government under Prime Minister Gordon Brown. During this government, the development minister, Secretary Douglas Alexander, and the finance minister, Alistair Darling, represented the UK in the Development Committee. The second British government was a twoparty coalition, uniting the Conservative Party (Tories) under Prime Minister David Cameron and the Liberal Democratic (LibDem) party. This government remained in office during the reform process and was represented by three conservative politicians: Development Ministers Andrew Mitchell and Justine Greening, and Finance Minister George Osborne.

Labour faced little opposition in the House of Commons during the first government: with 355 seats, the social democrats had an absolute majority with a 95-seat margin over the next two biggest parties - the LibDem (62 seats) and Conservative parties (198 seats) - combined, and a 157 margin over the next biggest party. The second government faced more opposition. On one hand, the liberals and conservatives still had respectively 57 and 306 seats, a margin of 105 seats over the next biggest Labour Party. However, the Tories alone had an edge of only 48 seats over Labour, and could thus expect more pressure to adopt preferences in line with social democratic positions.

The first British government strongly supported WB empowerment. Regarding services, the development and the finance ministers advocated expansion of the Bank's mandate to include climate change ${ }^{50}$ and sought to expand programs that facilitated "social protection." ${ }^{51}$ With regard to resources, officials called for more funding to expand the Bank's social safety net, and new financial mechanisms addressing the environment-development nexus. ${ }^{52}$ The government also pledged millions of pounds in additional contributions to funds focusing on social protection - such as the Rapid Social Response Fund - and to clean energy promotion. ${ }^{53}$ This emphasis on institutionalizing labor and environmental standards accords with our expectations for social democratic parties.

The conservative-liberal government that assumed office in 2010 sought even broader empowerment than its predecessors regarding Bank services. Officials supported the creation of new programs, such as a "blended lending policy" at the International Finance Corporation; ${ }^{44}$ expanded information

\footnotetext{
50 Alexander and Darling 2007.

$5^{1} \quad$ Alexander and Darling 2009, 1.

$5^{2}$ Alexander and Darling 2007, 3 .

53 Alexander and Darling 2008, 2009.

54 Mitchell and Osborne 2012.
} 
collection and analysis to improve Bank performance; ${ }^{55}$ and program expansion to more effectively meet gender, social protection, and job creation targets. ${ }^{56}$ Regarding resources, the UK proposed new financial mechanisms such as a performance-for-results instrument linking fund disbursement to policy achievements. ${ }^{57}$ Nonetheless, like the conservative French government, the British government attributed responsibility for enhancing the Bank's financial firepower to others, seeing the UK's existing contributions as "especially generous," and encouraging members to prioritize "economy and operating efficiently" in reference to Bank resources. ${ }^{58}$ The emphasis on efficiency and effectiveness mirrors our expectations for liberal and conservative parties, while the government's insistence that other members be responsible for resource IOE accords well with conservative positions. However, the emphasis on gender and social protection during the second government was surprising, seeming to be more compatible with social democratic positions.

We found support for the ministerial control expectation as well, given the preference changes evident from the first to the second government and, particularly, the dominance of conservative positions over liberal ones in the second government. Nonetheless, the party competition logic also appears relevant. Labour's dominance in the first government corresponds to social democratic dominance of government preferences, as this logic would predict. The inclusion of social democratic concerns in IOE preferences during the second government also corresponds to a relatively smaller margin of control for the Tories in the House of Commons vis-à-vis their largest competitor.

\subsubsection{The United States}

One-party governments held national office in the United States during the Bank reforms. Between 2007 and January 2009, the conservative Republican Party, led by President George W. Bush, was in charge. This administration's spokesperson at the Bank, Secretary of Finance Henry Paulson Jr., was a Republican Party member. From 2009 on, with the election of Democratic Party candidate Barack Obama as president, the control of the finance ministry passed into social democratic hands. The United States was represented by Timothy Geithner, the Secretary of Finance, and then Jacob Lew after 2013.

The Democrats controlled both houses of Congress during the first administration, holding 57 seats to the Republicans' 41 seats in the Senate, and 257 seats

$55 \quad$ Mitchell and Osborne 2011.

$56 \quad$ Greening and Osborne 2012; Mitchell and Osborne 2010.

57 Mitchell and Osborne 2012.

$5^{8}$ Mitchell and Osborne 2011, 2. 
to the Republicans' 178 seats in the House of Representatives. This suggests that the Republican secretary Paulson could expect opposition from Congress, which controls the administration's purse strings, should they disagree with his position on Bank reform. During the second administration, by contrast, Geithner and Lew were bolstered by a Democratic-controlled Senate - with a seat margin of four and eight seats over Republicans respectively in 2010 and 2012but constrained by a Republican House, where conservatives had slightly larger margins of control.

The Republican administration showed little support for Bank empowerment. With regard to services, Paulson supported expanding Bank programs to establish a "greater focus on private sector support and improving financial sector access. ${ }^{59} \mathrm{He}$ also called for the Bank to incorporate climate change in its mandate to ensure the success of development efforts. ${ }^{60}$ These statements underline efficiency and effectiveness over largesse, thereby aligning with conservatives' support for limiting the resources required by new IO initiatives. Paulson also sought to maintain the status quo, for example, by limiting Bank programs to those that "clearly meet [the Bank's] core mission." ${ }^{\text {61 }}$ Turning to resources, the government's willingness to contribute $\$ 2$ billion to the Bank's new Climate Investment Fund ${ }^{62}$ was surprising since conservatives can be expected neither to prioritize mandate expansion in environmental issues nor to support substantial expansion of IO resources. By contrast, emphasis on "optimal deployment" of existing Bank resources and "more budget discipline" ${ }^{\prime 3}$ do reflect conservatives' opposition to increasing resource obligations vis-à-vis the Bank.

During the Obama administration, statements from the Democrats showed support for services IOE, advocating for the adoption of new Bank rules to assess how well states support the "productive potential of women" and calling for the expansion of Bank programs combatting climate change. ${ }^{64}$ These preferences reflected Democrats' support for IOE as a means of institutionalizing environmental or labor standards beyond the individual state. However, most statements praised existing Bank services, addressing these issues rather than promoting further institutionalization of such standards through Bank empowerment. ${ }^{65}$ Regarding resources, Lew supported increasing the funding

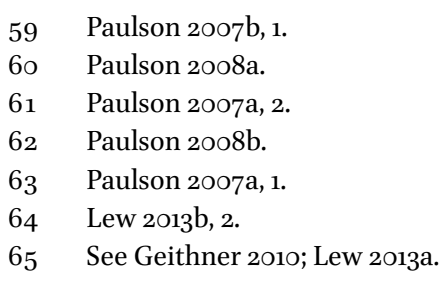


of the Global Agriculture and Food Security Program, underlining the United States' growing contributions and encouraging other states to follow suit. ${ }^{66}$ The US government supported expanding the Bank's capital base, but also saw a need to ensure that "any new resources will be managed well and used effectively."67 These positions reflect Democrats' preferences toward the international institutionalization of social standards and the strengthening of market regulation.

With respect to portfolio control, position statements generally aligned with the expected preferences of officials' party groups. This lends credence to our argument about ministerial control. Nonetheless, competition between executive and legislative branches also appears to be relevant. For instance, the first administration's support for resource IOE to fund climate change initiatives aligns better with the preferences of the Democratic-controlled Congress, while the second administration's prioritization of supporting existing rules over creating new ones echoes the limits that conservatives are expected to place on IOE. This suggests that the executive went some way toward meeting the legislature's preferences in determining positions toward Bank empowerment.

\subsection{Net Recipients and WB Empowerment \\ 2.2.1 Brazil}

Brazil was governed by one-party governments during the Bank negotiations. Between 2007 and 2010, the social democratic Workers' Party (PT) under the leadership of President Luiz Inácio Lula da Silva (henceforth, Lula) held office. The PT retained its position as the ruling party in 2011, but Lula was replaced by President Dilma Rousseff, who remained in office for the duration of the reforms. The PT finance minister Guido Mantega represented Brazil at the Bank under both administrations.

The PT controlled eighty-three seats in the Chamber of Deputies during the first government, putting it in second position behind the Christian Democratic Brazilian Democratic Movement Party (PMDB) with eighty-nine seats. The remaining legislative partners were mostly leftist or social democratic parties, including the Brazilian Communist Party (PCdoB) and the Brazilian Socialist Party (PSB), which together had sixty-two seats. The PT also had sixteen seats to the PMDB's thirty-one and the Social Democratic Party's (PDSB) twenty-one in the Federal Senate during the same period. That made the first

66 Lew 2013a.

67 Geithner 2009, 2, 2012. 
government a strong context within which to illustrate our argument on portfolio control. Power relations shifted in the Chamber of Deputies during the second government, with the PT now controlling more seats than the PMDB (eighty-seven and seventy-nine, respectively). Smaller leftist and social democratic coalition partners gained ground too, collectively holding seventy-seven seats in this period. However, the PMDB retained its control over the Senate, making this a weaker context for demonstrating the impact of ministerial control.

The first Brazilian government supported Bank empowerment. With regard to services, Minister Mantega supported additional monitoring by the Bank to determine the gender impact of Bank programs and sought to broaden the Bank's mandate to include issues such as food security and health pandemics. ${ }^{68}$ With respect to resources, Mantega repeatedly asked members to increase their contributions to the Bank's existing financial instruments, worrying that the Bank would be unable to provide support when developing countries needed it most. ${ }^{69}$ In addition, the Brazilian government supported expansion of World Bank capital, urging members to ensure that capital increases "proceed in a timely manner."70 These positions in favor of services and resources IOE to meet social development needs align with our expectations for social democratic parties. Unsurprisingly, they also align with Brazilian dependence on WB funds to improve its infrastructure and advance social development.

The Rousseff government demonstrated similar preferences to those of its predecessors. Starting with services, the government promoted the creation of new programs and the expansion of others to better respond to global economic challenges and to modernize the Bank. ${ }^{71}$ In addition, Minister Mantega asked the Bank to expand its monitoring and analytical services to evaluate the impact of agricultural subsidies on member states' development efforts. ${ }^{72}$ Turning to resources, Mantega considered the Bank's capital constraints "severe," with implications for the Bank's "relevance" as well as its capacity to meet new challenges, including natural disasters and economic shocks. ${ }^{73}$ The government's support for the reduction of economic inequality by promoting development echoes our expectations for social democratic parties. However, the government's rationale - that enhanced Bank material resources

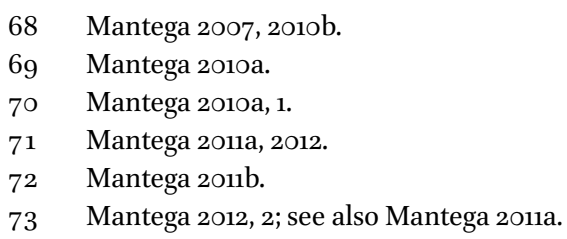


would give Brazil more opportunities to use Bank funds to decrease social inequality - is more in line with our expectations for left parties. But it corroborates the position of the Workers' Party on social inequality issues.

Overall, partisan positions and the ministry control shaped the preferences of the Brazilian government toward empowerment of the Bank. By contrast, the domestic institutions logic garnered only partial support. The other major party in the Brazilian legislature during the negotiations was the Christian democratic PMDB. While government's support for IOE to improve health, food security, and agricultural production was compatible with PMDB support for IOE to enhance citizen welfare, preferences that signify executive accommodation of positions that distinguish Christian democrats from the social democratic PT - for instance, declarations of support for the liberal world order or claims that IOE would constrain nationalism —-were not in evidence.

\subsubsection{India}

Two different types of governments held office in India during the reforms. The first, the United Progressive Alliance (UPA), was a multiparty coalition comprising the social democratic Indian National Congress (INC) party led by Prime Minister Manmohan Singh, with two leftist parties—namely, the Communist Party of India (CPI) and the Communist Party of India (Marxist) (CPI $[\mathrm{M}])$ - and several smaller parties. During this government, the INC finance minister P. Chidambaram and finance secretary Ashok Jha represented India at the WB. The second Indian government took office in May 2009. In this second government, the INC's dominance in the UPA coalition grew substantially as the INC gained additional seats and the communist parties withdrew. This was hence a multiparty coalition dominated by one party. India was represented by several officials at the WB during this government, including the INC finance ministers Pranab Mukherjee and P. Chidambaram and economics secretaries R. Gopalan and Ashok Chawla.

The INC held not only the ministerial portfolio but also a relatively larger share of seats in the parliament during the first government, 145 compared to the 53 held by the CPI and CPI(M) together. In terms of seats, the INC was dominant in the second government as well, holding 206 seats. This put the INC far ahead of its closest competitor, the conservative Bharatiya Janata Party (116 seats), as well as its biggest coalition ally, the leftist Samajwadi Party (22 seats). Given that the dominant coalition partner also held the ministerial portfolio in both cases, our ministerial control argument found only weak confirmation in this case.

The first government demonstrated support for Bank empowerment. With regard to services, officials supported expanding lending programs to meet 
increasing demand ${ }^{74}$ and called for selective expansion of the Bank's mandate to include issues of labor mobility, clean energy, and access to medicine. As Minister Chidambaram noted, "The scope of GPGs [global public goods] should be evolving with emerging global challenges and also include developing countries' concerns." ${ }^{75}$ Concerning resources, UPA statements emphasized the current underfunding of the Bank and proposed to increase states' contributions and the Bank's capital. ${ }^{76}$ Officials also called for new financial mechanisms, such as the Vulnerability Financing Facility, to generate additional resources for development projects. ${ }^{77}$ These positions favoring IOE conditionally on promoting social and environmental issues correspond to our expectations for social democratic parties, but contradict our expectations for the INC's leftist partners.

The second government displayed similar preferences to the first. As far as services were concerned, statements underlined Indian support for the Bank "constantly keeping the needs of the poor in sharp focus"78 to an even greater extent than in the previous UPA coalition. Officials repeatedly called for expansion of the Bank's lending services to middle-income countries as a means of refocusing the Bank's efforts on poor people rather than poor countries. ${ }^{79}$ This position aligns perfectly with India's status as a net recipient of the Bank's development assistance. The Indian government still considered resources to be inadequate to meet developing country needs given the world's financial crisis. ${ }^{80}$ Officials thus reiterated the previous government's support for increasing member contributions to Bank institutions and a general capital increase. ${ }^{81}$ These positions correspond to our expectations that social democratic support for IOE would be conditional on promoting social and labor standards. Furthermore, in both governments, INC control of the development portfolio provides support for our argument that the minister controlling an IO's portfolio shapes the government's position on IOE.

Nonetheless, the evidence does not perfectly fit our theoretical argument. Party competition reflected in legislature composition provides some clarifica-

\footnotetext{
74 Chawla 2009.

75 Chidambaram 2007, 2.

76 Chidambaram 2007; Chawla 2009.

77 Chawla 2009.

78 Gopalan 2011, 2.

79 Chawla 2010; Gopalan 2011.

8o Mukherjee 2oog.

81 Chidambaram 2013; Chawla 2010.
} 
TABLE 3 Support for different logics regarding how partisanship affects international organization empowerment (IOE)

How partisanship affects IOE preferences, via ...

\begin{tabular}{lcccc} 
Government & $\begin{array}{c}\text { Partisan } \\
\text { positions }\end{array}$ & $\begin{array}{c}\text { Control of } \\
\text { responsible } \\
\text { ministry }\end{array}$ & $\begin{array}{c}\text { Party } \\
\text { competition }\end{array}$ & $\begin{array}{c}\text { Conflicting } \\
\text { preferences among } \\
\text { domestic institutions }\end{array}$ \\
\hline Germany 1 & ++ & ++ & ++ & n.a. \\
Germany 2 & ++ & ++ & - & n.a. \\
France 1 & + & + & n.a. & - \\
France 2 & ++ & + & n.a. & - \\
United Kingdom 1 & ++ & ++ & ++ & n.a. \\
United Kingdom 2 & + & ++ & ++ & n.a. \\
United States 1 & + & + & n.a. & + \\
United States 2 & ++ & ++ & n.a. & + \\
Brazil 1 & ++ & ++ & n.a. & + \\
Brazil 2 & + & + & n.a. & + \\
India 1 & + & ++ & ++ & n.a. \\
India 2 & ++ & ++ & ++ & n.a. \\
\hline
\end{tabular}

++, strong support; +, conditional support; -opposition

tion. The INC dominated their leftist coalition partners in the first UPA coalition. While the emphasis on social objectives appeals to leftist concerns for social justice, the substance of the government's policy—namely, its support for IOE-reflects only the partisan position of the dominant INC. This was true in the second government as well. In other words, while partisan positions are an important factor to explain states preferences toward IOE, party competition was equally important in the Indian case. Table 3 shows how partisanship affects state preferences toward IOE.

\section{Conclusion}

We have argued that partisan positions and ministry control of an IO portfolio matter for understanding state preferences toward IOE. From the existing literature on domestic politics and international cooperation, we derived two expectations. First, partisan positions determine state preferences on IOE. Sec- 
ond, when a government is constituted by multiple parties, the position of the party controlling the ministry in charge of the IO portfolio shapes the government's position on IOE. We examined these expectations in six case studies, including four net donors and two net recipients of development assistance, and found that they held true in five cases.

This study was a first step toward examining the relationship between partisan positions, ministry control of an IO portfolio, and IOE. Future research should study the dynamics of partisanship and ministerial portfolio across countries and IOs in different policy areas over time. A second promising avenue would be to incorporate interviews with government and Bank officials and staff at the WB who liaise with member countries. Beyond partisanship and ministerial control, it would also be useful to investigate whether and how partisanship and ideology might undermine national interests. While in net donor states social democrats are willing to release funds and powers to IOs, left and right parties (even in net recipient states) appear unwilling to allow IOE even if it means higher funding. With the current wave of new populist parties across Europe and in the United States, this might have long-term implications for the level of IOE. This could be explored in future research by looking specifically at how left and right parties in net donor and net recipient states shape public opinion on IOE and increase discontent with the costs of global governance.

\section{Bibliography}

Alexander, Douglas, and Alistair Darling. "Statement." DC/S/2007-oo66. World Bank Development Committee, 21 October 2007.

Alexander, Douglas, and Alistair Darling. "Statement." DC/S/2008-oo56. World Bank Development Committee, 12 October 2008.

Alexander, Douglas, and Alistair Darling. "Statement." DC/S/20o9-oo3o. World Bank Development Committee, 26 April 2009.

Alternative for Germany. "Programm für Deutschland." 2017. https://www.afd.de/wahl programm/.

Andersen, Thomas Barnebeck, Henrik Hansen, and Thomas Markussen. "US Politics and World Bank IDA-Lending." Journal of Development Studies 42 (5) (2006), 772794.

Bakker, Ryan, Catherine de Vries, Erica Edwards, Liesbet Hooghe, Seth Jolly, Gary Marks, Jonathan Polk, Jan Rovny, Marco Steenbergen, and Milada Anna Vachudova. "Measuring Party Positions in Europe: The Chapel Hill Expert Survey Trend File, 19992010." Party Politics 21 (1) (2012), 143-152. 
Baroin, François. "Statement.” DC/S/2011-0059 (E). World Bank Development Committee, 24 September 2011.

Camyar, Isa. "Party Politics and International Trade: Mainstream Parties, Niche Parties, and Trade Openness." International Studies Quarterly 56 (2) (2012), 397404.

Chawla, Ashok. "Statement." DC/S/20o9-ool1. World Bank Development Committee. 26 April 2009.

Chawla, Ashok. "Statement." DC/S/2010-0o10. World Bank Development Committee, 25 April 2010.

Chidambaram, P. “Statement.” DC/S/2007-0055. World Bank Development Committee, 21 October 2007.

Chidambaram, P. "Statement." DC/S/2013-0o47. World Bank Development Committee, 12 October 2013.

Chin, Gregory T. "The BRICS-Led Development Bank: Purpose and Politics beyond the G2o." Global Policy 5 (3) (2014), 366-373.

Christian Democratic Union. "Regierungsprogramm 2009-2013." 2009. http://www.kas .de/upload/ACDP/CDU/Programme_Bundestag/20o9-2013_Regierungsprogramm_ Wir-haben-die-Kraft_Gemeinsam-fuer-unser-Land.pdf.

Clegg, Liam Simon. "In the Loop: Multilevel Feedback and the Politics of Change at the IMF and World Bank." Journal of International Relations and Development 13 (1) (2010), 59-84.

Coen, David, and Tom Pegram. "Wanted: A Third Generation of Global Governance Research." Governance 28 (4) (2015), 417-420.

Communist Party of India [Marxist]. "Manifesto." 2014. https://www.cpim.org/content/ cpim-manifesto-highlights.

Conceição-Heldt, Eugénia. Negotiating Trade Liberalization at the WTO: Domestic Politics and Bargaining Dynamics (Basingstoke: Palgrave Macmillan, 2011).

Conceição-Heldt, Eugénia. "Emerging Powers in WTO Negotiations: The Domestic Sources of Trade Policy Preferences." International Trade Journal 27 (5) (2013), 431449 .

Conceição-Heldt, Eugénia, and Patrick A. Mello. "Two-Level Games in Foreign Policy Analysis." In Oxford Research Encyclopedia of Politics, ed. William R. Thompson (Oxford: Oxford University Press, 2018). DOI 10.1093/acrefore/9780190228637.013 $.496 .1-31$.

Crawford, Beverly. "Explaining Defection from International Cooperation: Germany's Unilateral Recognition of Croatia." World Politics 48 (4) (1996), 482-521.

Democratic Party. "Moving America Forward." 2012. http://www.presidency.ucsb.edu/ papers_pdf/101962.pdf.

Döring, Holger, and Philip Manow. Parliaments and Governments Database. ParlGov. Development version, 2016. 
Finke, Daniel, and Tanja Dannwolf. "Domestic Scrutiny of European Union Politics: Between Whistle Blowing and Opposition Control." European Journal of Political Research $5^{2}$ (6) (2013), 715-745.

Fioretos, Orfeo, and Eugénia C. Heldt. "Legacies and Innovations in Global Economic Governance since Bretton Woods." Review of International Political Economy 6 (6) (2019), 1089-1111.

Free Democratic Party. “Die Mitte stärken: Deutschlandprogramm 20og.” 20og. https:// www.fdp.de/files/565/Deutschlandprogrammo9_Endfassung.pdf.

Geithner, Timothy. “Statement.” DC/S/20o9-0049. World Bank Development Committee, 5 October 2009 .

Geithner, Timothy. "Statement." DC/S/2010-0056. World Bank Development Committee, 9 October 2010.

Geithner, Timothy. "Statement." DC/S/2012-0035. World Bank Development Committee, 21 April 2012.

Gopalan, R. "Statement." DC/S/2011-0oo5. World Bank Development Committee, 16 April 2011.

Greening, Justine, and George Osborne. "Statement." DC/S/2012-0o58. World Bank Development Committee, 13 October 2012.

Hallerberg, Mark. "Electoral Laws, Government, and Parliament." In Patterns of Parliamentary Behavior: Passage of Legislation across Western Europe, eds. Herbert Döring and Mark Hallerberg (Aldershot: Ashgate, 2004), 11-34.

Hawkins, Darren G., David A. Lake, Daniel L. Nelson, and Michael J. Tierney, eds. Delegation and Agency in International Organizations (Cambridge: Cambridge University Press, 2006).

Heldt, Eugénia C. "Shaping Global Trade Governance Rules: New Powers' Hard and Soft Strategies of Influence at the WTO." European Foreign Affairs Review 22 (Special Issue) (2017), 19-36.

Heldt, Eugénia C. "Lost in Internal Evaluation? Accountability and Insulation at the World Bank." Contemporary Politics 24 (5) (2018), 568-587.

Heldt, Eugénia C. "Contested EU Trade Governance: Transparency Conundrums in TTIP Negotiations." Comparative European Politics 18 (2) (2020), 215-232.

Heldt, Eugénia C., and Laura C. Mahrenbach. "Rising Powers in Global Economic Governance: Mapping the Flexibility-Empowerment Nexus." Global Policy 10 (1) (2018), 19-28.

Heldt, Eugénia C., and Henning Schmidtke. "Measuring the Empowerment of International Organizations: The Evolution of Financial and Staff Capabilities." Global Policy 8 (S5) (2017), 51-61.

Heldt, Eugénia C. and Henning Schmidtke. "Global Democracy in Decline: How Rising Authoritarianism Limits Democratic Control over International Institutions.” Global Governance 25 (2) (2019a), 231-254. 
Heldt, Eugénia C., and Henning Schmidtke. "Explaining Coherence in International Regime Complexes: How the World Bank Shapes the Field of Multilateral Development Finance." Review of International Political Economy 6 (6) (2019b), 116o1186.

Hsieh, Hsiu-Fang, and Sarah E. Shannon. "Three Approaches to Qualitative Content Analysis." Qualitative Health Research 15 (9) (2005), 1277-1288.

Inter-Parliamentary Union. 2015. "PARLINE Database on National Parliaments."

Jakobeit, Cord. "Enhancing the Voice of Developing Countries in the World Bank." (German Ministry for Economic Cooperation and Development, 2004).

Koremenos, Barbara, Charles Lipson, and Duncan Snidal. “The Rational Design of International Institutions." International Organization 55 (4) (2001), 761-799.

Krippendorf, Klaus. Content Analysis, 3rd ed. (London: Sage, 2013).

Lagarde, Christine. "Statement." DC/S/2007-0065(E). World Bank Development Committee, 21 October 2007.

Lagarde, Christine. "Statement." DC/S/20o8-oo29(E). World Bank Development Committee, 13 April 2008.

Lagarde, Christine. "Statement." DC/S/2009-0059(E). World Bank Development Committee, 5 October 2009 .

Lagarde, Christine. "Statement." DC/S/2010-0058 (E). World Bank Development Committee, 9 October 2010 .

Lagarde, Christine. "Statement." DC/S/2010-oo16 (E). World Bank Development Committee, 25 April 201ob.

Lew, Jacob. "Statement." DC/S/2013-0o29. World Bank Development Committee, 20 April 2013a.

Lew, Jacob. "Statement." DC/S/2013-oo61. World Bank Development Committee, 12 October $2013 \mathrm{~b}$.

Mahrenbach, Laura Carsten. The Trade Policy of Emerging Powers (Basingstoke: Palgrave Macmillan, 2013).

Mahrenbach, Laura Carsten. "Deconstructing 'Emerging Powers' and 'Emerging Markets': India and the United States in Global Governance." India Quarterly 71 (4) (2015), $348-364$.

Mahrenbach, Laura C. "Conceptualising Emerging Powers." In The Palgrave Handbook of Contemporary International Political Economy, eds. Timothy M. Shaw, Laura C. Mahrenbach, Renu Modi, and Xu Yi-chong (Basingstoke: Palgrave Macmillan, 2019a), 217-232.

Mahrenbach, Laura C. "The Domestic Foundations of Emerging and Established State Trade Cooperation." In The International Political Economy of the BRICS, ed. Li Xing (London: Routledge, 2019b), 57-74.

Mantega, Guido. "Statement." DC/S/2007-0026. World Bank Development Committee, 15 April 2007. 
Mantega, Guido. “Statement.” DC/S/2010-0044. World Bank Development Committee, 9 October 2010 .

Mantega, Guido. "Statement." DC/S/2010-0023 World Bank Development Committee, 25 April 2010b.

Mantega, Guido. “Statement.” DC/S/2011-oo3o. World Bank Development Committee, 16 April 2011a.

Mantega, Guido. "Statement." DC/S/2011-oo61. World Bank Development Committee, 24 September 2011b.

Mantega, Guido. "Statement." DC/S/2012-0o29, World Bank Development Committee, 21 April 2012.

Marks, Gary, Carole J. Wilson, and Leonard Ray. "National Political Parties and European Integration." American Journal of Political Science 46 (3) (2002), 585594 .

Milliken, Jennifer. "The Study of Discourse in International Relations: A Critique of Research and Methods." European Journal of International Relations 5 (2) (1999), 225254.

Milner, Helen. Interests, Institutions, and Information: Domestic Politics and International Relations (Princeton: Princeton University Press, 1997).

Mitchell, Andrew, and George Osborne. "Statement." DC/S/2010-oo61. World Bank Development Committee, 9 October 2010.

Mitchell, Andrew, and George Osborne. "Statement." DC/S/2011-0o58. World Bank Development Committee, 24 September 2011.

Mitchell, Andrew, and George Osborne. "Statement." DC/S/2012-oo33. Development Committee, 21 April 2012.

Moravcsik, Andrew. "Taking Preferences Seriously: A Liberal Theory of International Politics." International Organization 51 (4) (1997), 513-553.

Moscovici, Pierre. "Statement." DC/S/2012-007o(E). World Bank Development Committee, 13 October 2012.

Moscovici, Pierre. "Statement." DC/S/2013-0032 (E). World Bank Development Committee, 20 April 2013.

Mukherjee, Pranab. "Statement." DC/S/2009-0o41. World Bank Development Committee, 5 October 2009 .

Müller, Wolfgang C., and Kaare Strøm, eds. Coalition Governments in Western Europe (Oxford: Oxford University Press, 2000).

Niebel, Dirk. "Statement." DC/S/2010-0035. World Bank Development Committee, 9 October 2010.

Niebel, Dirk. "Statement." DC/S/2011-0oo2. World Bank Development Committee, 16 April 2011a.

Niebel, Dirk. "Statement." DC/S/2011-oo39. World Bank Development Committee, 24 September 2011b. 
Niebel, Dirk. "Statement." DC/S/2012-ooo8. World Bank Development Committtee, 21 April 2012.

Niebel, Dirk. "Statement." DC/S/2013-0oo3. World Bank Development Committee, 20 April 2013.

Park, Susan. "Accountability as Justice for the Multilateral Development Banks? Borrower Opposition and Bank Avoidance to US Power and Influence." Review of International Political Economy 25 (6) (2017), 776-78o.

Paulson, Henry, Jr. DC/S/2007-0058. World Bank Development Committee, 21 October 2007a.

Paulson, Henry, Jr. “Statement.” DC/S/2007-0032. World Bank Development Committtee, 15 April 2007b.

Paulson, Henry, Jr. “Statement." DC/S/2008-0024. World Bank Development Committee, 13 April 2008a.

Paulson, Henry, Jr. “Statement.” DC/S/2008-0o64. World Bank Development Committee, 12 October 20o8b.

Republican Party. "We Believe in America." 2012. http://www.presidency.ucsb.edu/ws/ ?pid=101961.

Strøm, Kaare, Wolfgang C. Müller, and Daniel Markham Smith. "Parliamentary Control of Coalition Governments." Annual Review of Political Science 13 (2010), 517535 .

Vestergaard, Jakob, and Robert H. Wade. "Still in the Woods: Gridlock in the IMF and the World Bank Puts Multilateralism at Risk." Global Policy 6 (1) (2015), 1-12.

Wade, Robert. "The State of the World Bank." Challenge 53 (4) (2010), 43-67.

Weaver, Catherine. "The World's Bank and the Bank's World." Global Governance 13 (4) (2007), 493-512.

White, Howard, and Oliver Morrissey. "Conditionality When Donor and Recipient Preferences Vary." Journal of International Development 9 (4) (1998), 497-505.

Wieczorek-Zeul, Heidemarie. "Statement." DC/S/2007-oo21. World Bank Development Committee, 15 April 2007a.

Wieczorek-Zeul, Heidemarie. "Statement." DC/S/2007-0049. World Bank Development Committee, 21 October 2007b.

Wieczorek-Zeul, Heidemarie. "Statement." DC/S/2009-oo51. World Bank Development Committee, 5 October 2009 .

Winters, Matthew S., and Shyam Kulkarni. "The World Bank in the Post-Structural Adjustment Era." In Handbook of Global Economic Governance: Players, Power and Paradigms, eds. Manuela Moschella and Catherine Weaver (New York: Routledge, 2014), 251-266.

Wonka, Arndt. "The Party Politics of the Euro Crisis in the German Bundestag: Frames, Positions and Salience." West European Politics 39 (1) (2016), 125-144.

Woods, Ngaire. "Whose Aid? Whose Influence? China, Emerging Donors and the Silent 
Revolution in Development Assistance." International Affairs 84 (6) (2008), 12051221.

Woods, Ngaire. "Global Governance after the Financial Crisis: A New Multilateralism or the Last Gasp of the Great Powers?" Global Policy 1 (1) (2010), 51-63.

World Bank. 2010. "Biggest Donors by Countries—2010". World Bank, accessed July 3 o. https://finances.worldbank.org/Trust-Funds-and-FIFs/Biggest-donors-by-countries $-2010 /$ racs-ptjn/data 